\title{
A new theoretical model of government backed venture capital funding
}

\author{
BALÁZS FAZEKAS* (1) and PATRÍCIA BECSKY-NAGY
}

Faculty of Economics and Business, Institute of Accounting and Finance, University of Debrecen, Böszörményi út 138, H-4032, Debrecen, Hungary

Received: March 1, 2019 • Revised manuscript received: June 11, 2019 • Accepted: September 27, 2019

(C) 2021 The Author(s)

\begin{abstract}
Government involvement in the venture capital (VC) market has become an important catalyst of the entrepreneurial ecosystem of young and innovative firms. There is an extensive literature describing the VC model, but the models of its government backed variants are not comprehensively discussed. The article focuses on the model of purely government backed venture capital (GVC) and hybrid venture capital (HGVC). The conclusion of this article is that, by the logic of their models, GVCs are destined to underperform than private VCs. Many articles see HGVCs as a step forward compared to GVCs, as they involve private participants. The novelty of the current article lies in bringing out the drawbacks deriving from the system of hybrid venture capital funding by creating a complex theoretical framework of the HGVC model. We show that due to the crowding in of private participants, this scheme creates a two-goal system where the private profit maximising interests conflict with the economic policy goals. The complex system of HGVC is exposed to increased moral hazard issues that might lead to higher distortions than GVC. The conclusions are especially relevant in the case of developing industries.
\end{abstract}

\section{KEYWORDS}

venture capital, public policy, innovation, firm growth

JEL CLASSIFICATION INDICES

G14, G18, G24

*Corresponding author. E-mail: fazekas.balazs@econ.unideb.hu 


\section{INTRODUCTION}

Young and innovative small firms play an essential role in modern economies. There are many studies emphasising their importance in bringing radical innovations to market (Abernathy Utterback 1978; Scherer - Ross 1990; Kirchhoff 1993; Bower - Christensen 1995; Baumol 2002; Roszko-Wójtowicz - Białek 2018). Moreover, such enterprises also have a spurring effect on employment and economic growth. Regardless of their roles in economies, for a variety of reasons, such companies face difficulties in obtaining the necessary resources for growth due to market failures, such as information asymmetries and externalities, combined with the problems of high uncertainty and the lack of collateral (Gompers 1995; Philpott 1994; Mason - Harrison 1997; Hall 2002; Cressy 2002; Becsky-Nagy 2016). The institution of venture capital (VC) is supposed to provide a solution for the funding problems of these companies. In well-developed entrepreneurial economies, VC plays a major role in the funding of young and innovative enterprises; therefore, it is an important element of the innovation systems (Kenney 2011). The positive effects of enterprises that are in the scope of VC provide a strong foundation for public support, especially with regards to the market failures connected to them. As a result of information asymmetries, adverse selection (Akerlof 1970) and moral hazard issues (Jensen Meckling 1976) evolve. Additionally, the positive externalities of their innovation also result in sub-optimal levels of investment.

Government agendas aiming at the development of VC markets worked under the presumption that the inefficiencies of the supply side lag behind the relative underdevelopment of the market; therefore, the public sector tried to support private investors through direct interventions and filled in for them in their absence by providing a VC type funding.

The global financial crisis in 2008 and the increasing funding problems of small-and medium-size enterprises (SMEs), more specifically the young and innovative firms led to a more extensive involvement in the VC markets of Europe. Prior the crisis the amount of capital allocated into the VC industry in Europe by government agencies was relatively low (less than $10 \%$ of the total capital raised), but in the past decade the proportion of incremental capital raised by government agencies moved between $20 \%$ and $30 \%$ on average (Invest Europe 2016, 2019). However, the European market is not uniform in this sense. In different regions the role of government funding varies significantly. In the UK - where the VC industry shows a great resemblance to the most developed US VC market - government funding has a lesser role relatively, but in the funding of early stages even in the UK public funds had a prominent role after the recession (Pierrakis 2010). On the other hand, the developing industries of CEE rely mostly on state subsidy.

The current article focuses on the questions regarding the design of government VC agendas and aims to create a new model of government VC. The article discusses the theoretical framework of different forms of government direct involvement; pure government venture capital funds (GVCs) and hybrid venture capital funds (HGVCs). While in theory the primary goal of both types is to alleviate the funding problems of young and innovative enterprises and, in this sense, they are similar to market-backed private venture capital (PVC), the underlying incentives are different and they - by their very nature - lead to different results on the market. The questions regarding the efficiency of government interventions will be discussed in the context of the theoretical models of GVCs and HGVCs. 


\section{LITERATURE REVIEW}

Although there are many types of government interventions in the venture capital market, there are two underlying assumptions that are common in these agendas; first, because of market failures, there is insufficient funding for new, innovative companies and second, governments are able to mend these failures either by selecting and financing viable enterprises or by influencing the market in order to spur these activities (Lerner 2002).

If the government program focuses on the selection and funding of the enterprises, then we are talking about the direct involvement of government, where the public agencies are imitating the PVCs and replacing them. On the other hand, when the government programs are influencing the ecosystem of new, innovative firms and the private participants in order to appear on the VC market, then governments exercise their indirect role in developing an industry.

Direct interventions on the VC market or the active roles of government denote the VC-oriented use of government funds when government provides capital for VC funds and manages them or influences their management. The foundation of these programs is that, as a result of market failures, funding gaps evolve, and viable enterprises are not able to obtain capital (Harding 2002).

HGVCs appeared in the field of direct interventions in addition to GVCs. HGVCs represent the cooperation of market and government backed participants, where the capital is provided at least partially by the public sector. Although its use is regulated by government, the actual management of funds is the responsibility of private participants. By its logic, HGVCs are built on the approaches of an active (by providing capital) and a passive role (incentivising market participants to appear on the VC market) of government.

Built on the idea that the cooperation with private participants increases the effectiveness of government backed VC agendas, several HGVC type programs were launched in Israel, New Zealand, Canada, Australia, Finland, the UK, China and with the promotion of the European Regional Development Fund (ERDF) in the developing VC industries of the Southern and the CEE countries.

VC influences the economy indirectly through the performance of the invested enterprises. Table 1 summarises the literature focusing on the performance of VC backed firms.

The vitalization of VC markets through direct state (or government) interventions is far from being unprecedented. Becker - Hellmann (2005) examined the first German VC fund created in 1975 with the support and involvement of government. The authors point out that this initiation failed ultimately as the government backed fund was unable to imitate the special value creating mechanisms of PVC. Moreover, at the same time, the entrepreneurial environment was not fitting for professional VCs. Engel - Keilbach (2007) identified the reasons for the latter boom of the German VC market in 1995-2000 in the improvement of stock exchange for smaller firms, the appearance of technology-oriented new firms and the establishment of a coinvestment hybrid fund. They showed that in Germany, the VC enterprises had higher growth rates and increased patent activity, although patents were applied before the investments were made. Therefore, they concluded that VC assisted the companies in commercialisation rather than in R\&D. By examining the Belgian market, Manigart et al. (2002) found that the survival rate of the VC backed companies was lower than for the non-VC backed companies, especially if the VC was backed by the government. Also based on evidence from the Belgian market, Alperovych et al. (2015) found that the government VC backed firms achieved lower productivity compared to their PVC peers - even compared to the non-VC backed firms. 
Table 1. The summary of the literature focusing on a comparative analysis of the performance of VC-backed firms

\begin{tabular}{|c|c|c|c|}
\hline Article & Research area & Data & Findings \\
\hline \multicolumn{4}{|c|}{ Research papers focusing on the performance comparison of VC-backed and non-VC backed firms } \\
\hline Megginson - Weiss (1991) & Certificating effect of venture capital. & $\begin{array}{l}320-320 \mathrm{VC} \text { and non-VC enterprises in } \\
\text { the US that went through an IPO in } \\
1983-1987 \text { (paired sample by activity). }\end{array}$ & $\begin{array}{l}\text { VC has positive certification. } \\
\text { Underpricing had less probability and } \\
\text { spreads in early trading were lower for } \\
\text { VC-backed enterprises. }\end{array}$ \\
\hline Hellmann - Puri (2000) & $\begin{array}{l}\text { The strategies and innovation } \\
\text { performance of VC-backed firms. }\end{array}$ & $\begin{array}{l}173 \text { Silicon Valley based high-tech } \\
\text { firms. } 2 / 3 \text { rd VC-backed, } 1 / 3 \text { rd not } \\
\text { (paired sample based on activity). }\end{array}$ & $\begin{array}{l}\text { The innovators were able to obtain VC } \\
\text { with higher probability than the } \\
\text { imitators and deliver their products to } \\
\text { the market faster. }\end{array}$ \\
\hline Brau et al. (2004) & $\begin{array}{l}\text { Performance of VC-backed firms after } \\
\text { IPO and its determinants. }\end{array}$ & $\begin{array}{l}126 \text { VC and } 108 \text { non-VC backed listed } \\
\text { small manufacturing firms in the US in } \\
1990-1996 \text { (paired sample based on } \\
\text { activity and indicators). }\end{array}$ & $\begin{array}{l}\text { Underwritings of VC-backed firms were } \\
\text { more successful ( } 90 \% \text { for VC and } 67 \% \\
\text { for non-VC), but no difference after } \\
\text { IPO. }\end{array}$ \\
\hline Engel - Keilbach (2007) & $\begin{array}{l}\text { Effect of VC on firm's growth and } \\
\text { innovation. }\end{array}$ & $\begin{array}{l}274 \text { VC-backed firms founded in 1995- } \\
1998 \text { in Germany (paired sample, } \\
\text { propensity score matching). }\end{array}$ & $\begin{array}{l}\text { The VC-backed firms had higher } \\
\text { growth rates, but they were no } \\
\text { different than non-VC firms in terms of } \\
\text { innovation. }\end{array}$ \\
\hline Coakley et al. (2007) & $\begin{array}{l}\text { Performance of VC-backed firms after } \\
\text { IPO. }\end{array}$ & $\begin{array}{l}316 \mathrm{VC} \text { and } 274 \text { non-VC backed firms } \\
\text { listed on the stock exchange in the UK } \\
\text { in } 1985-2003 .\end{array}$ & $\begin{array}{l}\text { VC has positive certification; however, } \\
\text { they underperformed in the dotcom } \\
\text { bubble. }\end{array}$ \\
\hline Peneder (2010) & $\begin{array}{l}\text { Effect of VC on firm's growth and } \\
\text { innovation. }\end{array}$ & $\begin{array}{l}132-132 \mathrm{VC} \text { and non-VC backed firms } \\
\text { in Austria (paired sample, propensity } \\
\text { score matching). }\end{array}$ & $\begin{array}{l}\text { VC had a positive effect on } \\
\text { employment and revenue growth. More } \\
\text { innovative firms are selected by VC but } \\
\text { the cooperation does not lead to } \\
\text { higher innovation. }\end{array}$ \\
\hline
\end{tabular}

(continued) 
Table 1. Continued

\begin{tabular}{|c|c|c|c|}
\hline Article & Research area & Data & Findings \\
\hline Chemmanur et al. (2011) & $\begin{array}{l}\text { The efficiency of VC-backed firms. What } \\
\text { is the source of efficiency? (Selection or } \\
\text { cooperation) }\end{array}$ & $\begin{array}{c}\text { US firms obtained VC in } 1972-2000 \\
\text { (paired sample with propensity score } \\
\text { matching and efficiency measured with } \\
\text { total factor productivity). }\end{array}$ & $\begin{array}{l}\text { VC improves efficiency. Selection and } \\
\text { cooperation both provide added value } \\
\text { for firms. Investors with 'good } \\
\text { reputation' reached higher growth and } \\
\text { efficiency. }\end{array}$ \\
\hline Puri - Zarutskie (2012) & $\begin{array}{l}\text { Effect of VC on firm's growth, survival } \\
\text { and profitability. }\end{array}$ & $\begin{array}{c}\text { 7632-7632 VC and non-VC backed US } \\
\text { firms obtained capital in 1981-2001 } \\
\text { (paired sample). }\end{array}$ & $\begin{array}{l}\text { VC-backed firms had higher growth, } \\
\text { but there was no difference in } \\
\text { profitability. The probability of } \\
\text { bankruptcy decreases in the } \\
\text { beginning, then it is similar. }\end{array}$ \\
\hline Croce et al. (2013) & $\begin{array}{l}\text { Differences of VC and non-VC backed } \\
\text { firms. }\end{array}$ & \begin{tabular}{|c|} 
VICO database (7 European countries) \\
$267-429$ VC and non-VC backed firms \\
in 1984-2010 (total factor productivity \\
and propensity score matching).
\end{tabular} & $\begin{array}{l}\text { The selection of the European funds } \\
\text { did not create value, but the } \\
\text { productivity of VC-backed firms } \\
\text { improves. This effect is permanent in } \\
\text { the long-run. }\end{array}$ \\
\hline Pommet (2017) & Survival rate of VC-backed firms. & $\begin{array}{c}122 \text { VC-backed and } 87 \text { non-VC backed } \\
\text { French firms that went through IPO in } \\
1996-2006 .\end{array}$ & $\begin{array}{l}\text { The survival rate did not improve, but } \\
\text { the duration of investment had a } \\
\text { positive effect on survival. }\end{array}$ \\
\hline \multicolumn{4}{|c|}{ Research papers focusing on the performance comparison of PVC backed and government sponsored VC backed firms } \\
\hline Lerner (1999) & $\begin{array}{l}\text { What are the long-term effects of } \\
\text { government backed VC? }\end{array}$ & $\begin{array}{c}541 \text { high-tech firms funded by SBIR in } \\
\text { the US in 1985-1995 and } 594 \text { non- } \\
\text { funded firms (paired sample by } \\
\text { activity). }\end{array}$ & $\begin{array}{l}\text { The firms funded by the government } \\
\text { agenda had higher growth in terms of } \\
\text { revenues and employment. }\end{array}$ \\
\hline
\end{tabular}




\begin{tabular}{|c|c|c|c|}
\hline Article & Research area & Data & Findings \\
\hline Manigart et al. (2002) & $\begin{array}{c}\text { The effect of government backed VC } \\
\text { compared to non-VC firms on survival. }\end{array}$ & $\begin{array}{l}565 \text { VC-backed ( } 71 \% \text { of the } \\
\text { government VC) and } 565 \text { non-VC } \\
\text { Belgian firms in 1987-1997 (paired } \\
\text { sample based on various indicators). }\end{array}$ & $\begin{array}{l}\text { In general, there is no difference in } \\
\text { terms of survival. However, the more } \\
\text { experienced the investors are, the } \\
\text { lower the probability of bankruptcy is. }\end{array}$ \\
\hline Cumming - Johan (2010) & $\begin{array}{c}\text { Differences between PVC and } \\
\text { government backed VC in duration and } \\
\text { exit. }\end{array}$ & $\begin{array}{l}557 \text { Canadian and } 1607 \text { US based } \\
\text { firms that obtained capital between } \\
1991 \text { and } 2004 \text {. }\end{array}$ & $\begin{array}{l}\text { The proportion of IPO was lower for } \\
\text { government backed VCs; these firms } \\
\text { exited earlier, which shows lower } \\
\text { added value. }\end{array}$ \\
\hline Bertoni - Tykova (2012) & $\begin{array}{l}\text { The effect of the type of investor } \\
\text { (government or private) and form } \\
\text { (syndicated or not) on firm innovation. }\end{array}$ & $\begin{array}{c}159 \text { VC-backed and } 706 \text { non-VC } \\
\text { backed biotech and pharmaceutical } \\
\text { firms in 1994-2004 from } 7 \text { European } \\
\text { countries (propensity score matching). }\end{array}$ & $\begin{array}{l}\text { The PVC and syndication increased } \\
\text { innovation performance; government } \\
\text { investments alone did not. } \\
\text { Government funding had a positive } \\
\text { effect if it supplemented the lead PVC } \\
\text { investor. }\end{array}$ \\
\hline Luukonen et al. (2013) & $\begin{array}{l}\text { Value created by government VC and } \\
\text { PVC and the methods of value creation. }\end{array}$ & $\begin{array}{l}284 \text { VC-backed firms (VICO database, } \\
\text { 1984-2004). Questionnaire about VC } \\
\text { services. }\end{array}$ & $\begin{array}{l}\text { Government VC creates less value for } \\
\text { invested firms and has lesser services } \\
\text { aiming at non-financial value creation. }\end{array}$ \\
\hline Grilli - Murtinu (2014) & $\begin{array}{l}\text { Differences of government backed and } \\
\text { PVC firms. }\end{array}$ & $\begin{array}{l}538 \text { PVC, } 239 \text { government backed and } \\
126 \text { mixed funding firms of VICO } \\
\text { database in 1984-2004 (propensity } \\
\text { score matching). }\end{array}$ & $\begin{array}{l}\text { The single government investor did not } \\
\text { improve the firm's performance; they } \\
\text { created a value in syndicated } \\
\text { investments with PVC. }\end{array}$ \\
\hline Alperovych et al. (2015) & $\begin{array}{c}\text { Differences of government backed, PVC } \\
\text { and non-VC backed firms. }\end{array}$ & $\begin{array}{l}515 \text { Belgian firms obtained capital in } \\
1998-2007 \text { (paired sample). }\end{array}$ & $\begin{array}{l}\text { The productivity of government backed } \\
\text { VC is lower but there is no significant } \\
\text { difference between efficiency. } \\
\text { Efficiency of the government backed } \\
\text { firm efficiency is lower than non-VC } \\
\text { backed firms. }\end{array}$ \\
\hline
\end{tabular}


Table 1. Continued

\begin{tabular}{|c|c|c|c|}
\hline Article & Research area & Data & Findings \\
\hline Brander et al. (2015) & $\begin{array}{l}\text { Differences of government backed and } \\
\text { PVC firms. }\end{array}$ & $\begin{array}{c}20,446 \text { firms from } 25 \text { countries in } \\
2000-2008 \text {. Companies traced up to } \\
2012 \text {. }\end{array}$ & $\begin{array}{l}\text { Government funds supplement rather } \\
\text { than substitute PVCs. Syndicated PVC } \\
\text { and government investments } \\
\text { performing the best, sole government } \\
\text { investors fall behind PVCs. }\end{array}$ \\
\hline \multicolumn{4}{|c|}{ Research papers focusing on the performance comparison of HGVC backed and otherwise financed firms } \\
\hline Nightingale et al. (2009) & $\begin{array}{l}\text { The effect of HGVCs on invested } \\
\text { companies. }\end{array}$ & $\begin{array}{l}782 \text { HGVC-backed firms in the UK } \\
\text { (paired sample comparison). }\end{array}$ & $\begin{array}{l}\text { The HGVC-backed firms had higher } \\
\text { employment and labour efficiency. } \\
\text { Profitability shows a 'U' shape in time. }\end{array}$ \\
\hline Cumming - Johan (2016) & HGVC effect on invested firms. & $\begin{array}{l}\text { Comparison of Australian PVC and } \\
\text { Innovation Investment Fund. }\end{array}$ & $\begin{array}{l}\text { Government backed investor proved to } \\
\text { be efficient in spurring innovation, } \\
\text { employment and market } \\
\text { capitalization. }\end{array}$ \\
\hline $\begin{array}{l}\text { Fazekas - Becsky-Nagy } \\
\text { (2018) }\end{array}$ & $\begin{array}{l}\text { HGVC and GVC effect on firm's growth } \\
\text { and innovation. }\end{array}$ & $\begin{array}{l}340 \text { HGVC and } 86 \text { GVC backed } \\
\text { Hungarian firms receiving funding in } \\
2010-2016 \text {. Comparison of revenues, } \\
\text { employment and patent activity. }\end{array}$ & $\begin{array}{l}\text { GVCs generated higher growth in terms } \\
\text { of revenues and employment than } \\
\text { HGVCs, but none of them could } \\
\text { significantly increase innovation. }\end{array}$ \\
\hline
\end{tabular}

Source: Own compilation. 
The studies mentioned above focus on the country-specific case studies. In addition to these studies, more research was carried out examining the effects of the government backed VC based on international evidence. They give a comprehensive analysis of government $\mathrm{VC}$ and they do not make specific conclusions regarding the unique aspects of regulation. Rather, they make general conclusions about VC.

Bertoni - Tykova (2012) investigated 7 European countries focusing on the biotech and healthcare industries in 1994-2004. Based on their results, the government backed VCs fell behind PVCs and as single investors, they were not able to improve the performance of the invested firms. Government backed investors were able to provide value in syndicated investments with PVCs as the lead investors.

Brander et al. (2015) investigated the effects of government backed VC funds by analysing 20,446 investments made in 2000-2008 in 25 countries. They measured the success of investment on the basis of exits. According to their results, the government backed funds were able to improve exit prospects as minority owners if they made their investments together with PVCs. However, as lead investors, they were less efficient than their private peers. They had the same conclusions on the Canadian market. One way this supports the notion that the government backed VC is not able to imitate the value enhancing mechanisms of PVCs and its services are limited to the provision of capital (Schilder 2006). Alternatively, Brander et al. (2015) explained these results with the economic policy aspects of government backed funds where investors broaden the scope of possible investment targets and provide capital even for those enterprises that could not obtain it based on purely market rationales. These results are also consistent with the findings of Gompers (1995), who stated that in the case of government investments, profit maximization is biased, as governments have economic policy functions, as well.

By using the VICO database covering the firms of 7 countries, Grilli - Murtinu (2014) examined the growth of revenues and employment. They had similar results to Brander et al. (2015); as lead investors government backed funds could not enhance the growth of the invested companies, while coupled with independent funds they were able to improve it. Luukkonen et al. (2013) confirmed via questionnaire that government backed funds lag behind their independent peers in terms of non-financial value added services, especially in strategic support, management assistance, enhancing growth and preparing exit.

International evidence suggests that GVC spurs firm performance in syndicated investment in cooperation with independent PVCs (Bertoni - Tykova 2012; Brander et al. 2015; Cumming et al. 2017; Grilli - Murtinu 2014). With PVC as a lead investor and GVC as a minority investor the advantages of both forms can prevail. The special expertise and the non-financial value added services of PVC can support the firm's performance, while the financial support of GVC can mend problems deriving from low capital. Especially in the European markets the additional capital provided by the GVC might have higher marginal contribution as the average investment size is lesser compared to the US investments. Therefore, syndicated investments with GVC as a minority investor might benefit from the positive synergies of different VC schemes.

\subsection{Effects of hybrid venture capital funds on invested enterprises}

In most cases, the studies mentioned above did not discuss the form of government funding; a fund is considered to be government backed if the government takes part directly in its 
operation either by providing capital or management assistance. Studies making a distinction between GVCs and HGVCs are relatively rare.

A research investigating the effects of hybrid funds in the UK concluded that these funds had modest but positive effect on the segment of young and innovative firms (Nightingale 2009). According to this research, both demand and supply side inefficiencies led to the modest results of these funds. Although there were irrational criteria in regulation, the demand side was not prepared to absorb this capital efficiently. More studies emphasize the demand side inefficiencies as the main reason for the relative underdevelopment of the European VC market (Becker Hellmann 2005; Engel - Keilbach 2007; Veugelers 2011; Murray et al. 2012).

The findings of Cumming - Johan (2016) are unique in the empirical studies examining the effects of government VC backed firms, as on the Australian market HGVCs were able to outperform their PVC peers in terms of spurring employment and innovation.

Brander et al. (2015) provided a detailed discussion about the effects of different type of government funds. Their general result was that the government backed VCs underperformed than their PVC peers, but they found evidence that HGVCs improved the exit prospects of firms compared to the pure GVCs. The relevance of HGVCs, furthermore, is that their appearance increased the amount of capital invested into PVCs, so they were able to attract further participants to the VC market. This suggests that HGVCs have a crowd in rather than a crowd out effect.

A research investigating the effects of HGVCs and GVCs of the Hungarian investments made in 2010-2016 found evidence that the hybrid venture capital backed firms generated lower growth and employment than their purely government backed VC financed peers. Both forms' firms showed meagre activity in the field of innovation (Fazekas - Becsky-Nagy 2018). The authors concluded that the inefficient design of the Hungarian HGVC scheme led to high moral hazards that hindered the efficient use of public funds.

\section{THE THEORETICAL MODEL OF VENTURE CAPITAL AGENDAS}

\subsection{The theoretical model of purely government backed venture capital agendas}

The systematic approach of the PVC model is in the focus of many studies (Gompers - Lerner 1998; Lerner 2003; Metrick 2007; Da Rin et al. 2011). In contrast, as the role of the government backed VC is increasing especially in the developing industries, the model of government backed VC is becoming increasingly important. Differences in the PVC's and GVC's models run much deeper than the source of capital. Table 2 contains the comparison of the models.

The GVC model differs from the PVC model in various aspects and its system is built on a different logic. Both models put young and innovative firms into their centers, but with different motives. In the PVC model, young and innovative companies provide a market niche where - as a result of market imperfections - other market participants are not willing or able to appear. This niche provides an opportunity for investors to exploit the economic potential of these companies in order to maximize their profits. In this sense, funding them is a necessary tool for gaining extra profits. Therefore, by its very nature, PVC is targeting the young and innovative companies.

Although the targeted firms of GVC are also the young and innovative enterprises, its model relies on different motives. While the essence of PVCs is the private interest that drives them in 
Table 2. The comparison of the models of private and government backed VC

\begin{tabular}{|c|c|c|c|}
\hline Feature & Private venture capital & $\begin{array}{l}\text { Government backed } \\
\text { venture capital }\end{array}$ & $\begin{array}{l}\text { Hybrid government } \\
\text { venture capital }\end{array}$ \\
\hline Investment focus & $\begin{array}{l}\text { Young and innovative } \\
\text { companies with high } \\
\text { growth potential. }\end{array}$ & $\begin{array}{l}\text { Young and innovative } \\
\text { companies with high } \\
\text { growth potential. }\end{array}$ & $\begin{array}{l}\text { Young and innovative } \\
\text { companies with high } \\
\text { growth potential. }\end{array}$ \\
\hline Goal of investment & $\begin{array}{l}\text { Profit maximization led by } \\
\text { private interests, increasing } \\
\text { the value of invested firm } \\
\text { and exiting it with high } \\
\text { profits. }\end{array}$ & $\begin{array}{l}\text { Profit maximization } \\
\text { adjusted with development } \\
\text { policy goals. Improving the } \\
\text { innovative capabilities and } \\
\text { economic growth of a given } \\
\text { region/country by using } \\
\text { budgetary funds to finance } \\
\text { young and innovative firms. }\end{array}$ & $\begin{array}{l}\text { Profit maximization led by } \\
\text { private interests } \\
\text { accordingly to government } \\
\text { regulation. Two goal } \\
\text { system with the economic } \\
\text { policy rationales } \\
\text { connected to government } \\
\text { funds and the profit } \\
\text { maximization motives of } \\
\text { private participants. }\end{array}$ \\
\hline General partners & $\begin{array}{l}\text { Financial intermediaries } \\
\text { with business expertise. }\end{array}$ & $\begin{array}{l}\text { Financial intermediation } \\
\text { through government } \\
\text { agencies (bureaucratic } \\
\text { allocation). }\end{array}$ & $\begin{array}{l}\text { Financial intermediaries } \\
\text { selected by government } \\
\text { agencies (mix of } \\
\text { bureaucratic and market } \\
\text { allocation). }\end{array}$ \\
\hline Limited partners & $\begin{array}{l}\text { Well diversified institutional } \\
\text { investors. }\end{array}$ & Government funding. & $\begin{array}{c}\text { Government and private } \\
\text { funding. }\end{array}$ \\
\hline Type of funding & Mainly equity financing. & $\begin{array}{l}\text { Mainly equity financing, but } \\
\text { debt financing also } \\
\text { significant. }\end{array}$ & Mainly equity financing. \\
\hline $\begin{array}{l}\text { Cooperation of } \\
\text { investor and firm }\end{array}$ & $\begin{array}{l}\text { Strategic support, active } \\
\text { involvement in the } \\
\text { management and } \\
\text { monitoring of firms. }\end{array}$ & $\begin{array}{l}\text { Primarily monitoring } \\
\text { function. }\end{array}$ & $\begin{array}{l}\text { Strategic support, active } \\
\text { involvement in the } \\
\text { management and } \\
\text { monitoring of firms. }\end{array}$ \\
\hline
\end{tabular}

Source: Own compilation.

creating and managing their portfolios, in the case of GVCs, although the profit maximization also appears as a goal, it is adjusted and sometimes even overwritten by economic policy rationales. The presumption of government intervention is that the supply of VC is sub-optimal and government funds can decrease welfare losses (Berger - Udell 1998). Of course, funding young and innovative enterprises is a tool, but in this case, it is a tool for spurring innovation, employment and economic growth. In theory, this goal could be consistent with profit maximizing behaviour, but if these firms were likely to be successful in commercial terms as well, then private investors would fund them. In this case, the economic policy rational overwrites the profit maximizing behaviour. This conclusion is strengthened by the results of Bertoni et al. (2015), who investigated the specific features of the European VCs with regards to the 
background of limited partners. Based on their study, GVCs focus is on those young and innovative companies that do not meet the requirements of other VCs, mostly in seed stage with specific industries. The economic policy-related decisions of GVCs are not consistent with PVCs therefore the number of syndicated investments is relatively low.

This inconsistency of goals hinders the efficient selection of firms. However, it is doubtful whether the government agencies are able to tackle the problems that market participants could not. Therefore, GVCs could lead to market distortions. If GVCs operate in an environment where information imperfections remain unresolved, then the funding of firms would lead to an adverse selection when the targeted companies are able to obtain capital, even though they are not viable. In addition to the short-term effect (low quality of the investments) on the long-run, the prospects of young and innovative firms might get even worse, as the poor performance of GVCs leads to worse valuation for these enterprises.

There is also a difference in the dimension of cooperation between PVC and GVC. There is a consensus in the literature about the role of venture capitalist special expertise (Fried - Hisrich 1994; MacMillan et al. 1998; Harding 2002; Lerner 2003; Fazekas 2016; Becsky-Nagy - Fazekas 2015). This special expertise provides a foundation for PVCs to overcome the market imperfections more efficiently than other private participants. Based on international evidence, general partners (GP) of GVCs are less experienced and less efficient in the identification of viable investment targets (Cumming - Macintosh 2006; Avinimelech - Teubal 2006; Becsky-Nagy Fazekas 2017). Lerner (2003) emphasises that VC is not a uniform asset class, as there is a high heterogeneity in the non-financial value added services provided by the investors. This is also confirmed by the high variance of VCs returns (Kaplan - Schoar 2005; Phalippou 2010; Phalippou - Gottschalg 2009; Harris et al. 2014). The performance of VCs depends on the structural factors of capital, competence and cooperation (Becsky-Nagy 2016). Furthermore, these factors show a dynamic development; the more experienced the VCs are, the more valuable their nonfinancial services are. Cooperation with GVCs is limited to the monitoring of firms; therefore, they are not able to implant the necessary competence and bridge the knowledge gap for young and innovative firms. This is consistent with the international evidence that suggests that GVCs are able to improve the invested firms' performance only if they supplemented PVCs. In the absence of close cooperation and control, the quality of the investments might decrease (Devenow - Welch 1996).

Both PVC and GVC models represent some form of financial intermediation with information asymmetries. At first Sahlman (1990) provided a detailed discussion of the two-level principal agent relationship and the complex moral hazard issues that evolve in the PVC model. In the GVC model, where the limited partners (LP) are public agencies, the process becomes more exposed to the moral hazard issues, as in the case of public funds a multi-level principalagent relationship evolves (Lane 2000). While in the PVC model, there are various practices reducing the risks of principal-agent relationship, in the case of GVC, the extent of the problem depends on the regulation, transparency and institutional environment of the system. However, a strict regulation might restrict the efficient operation of investors (Karsai 2018). Baldock (2016) highlighted based on international evidence that overregulation in terms of government agendas' scale and scope might hinder efficiency.

GVCs by their nature are not able to imitate the cooperation and the strategic assistance of PVCs and, at the same time, economic policy goals hinder the efficient selection of the firms. The model of GVCs (its different goals and the tools connected to them) therefore predestines 
the poorer performance of the GVC backed enterprises. The international evidence supports the conclusions of this model. It is also obvious based on the theoretical and empirical evidence that in the long run, an efficient VC market cannot rely on GVCs. It is also out of the question that young and innovative firms are essential parts of a healthy entrepreneurial system. In the absence of PVCs, the only rational goal of the GVC schemes can be to develop the market to a point where private participants are willing and able to sustain the VC market. The role of GVCs is to catalyse the development process. In this sense, the indirect effects of GVCs on the ecosystem of young and innovative firms is even more important than their direct effects on the invested companies. These agendas cannot be evaluated purely on the basis of the performances of the invested firms. Within the indirect effects, we can mention the accumulated experiences and the learning processes of market participants that are generated via GVCs' investments. Especially in the case of an emerging market's developing infant industry, the knowledge generated by the investments may lead to the formation of an ecosystem that could attract PVCs.

\subsection{The theoretical model of hybrid venture capital agendas}

3.2.1. Incentive schemes of HGVCs. HGVC has become an increasingly dominant form of government backed VC. The goal of hybrid VC agendas is to overcome the inefficiencies of the GVC model by attracting private investors. In theory, HGVC is a step forward towards a selfsustaining VC market as it relies on the participation of the private sector. In theory, as HGVC incorporates the competence of private investors, their superior non-financial value added services lead to a more efficient use of public funds. Yet, the complex system and the incentives built into HGVCs might lead to various distortions and to the misuse of public funds.

As in PVC there is a two-level principle-agent relationship, the properly designed incentive scheme became an important element of the private funding model. The success of PVC scheme relies on overcoming the moral hazards between the limited and general partners by harmonizing their interests. In PVC carried interests and the contribution of LPs to the fund's capital are the most commonly used tools that harmonize the participants' goals by incentivizing LPs to select and manage the invested firms to the best of their abilities. Incentives create a funding scheme where these actions maximise the utility of LPs and GPs and at the same time lead to the efficient allocation of resources.

In contrast to the PVC model, in HGVC the role of incentive scheme is not only to harmonize the interests of LPs and GPs. A pivotal question of these agendas is how to incentivize the private participants to take part in the funding of young and innovative firms. Table 3 summarises the commonly used incentive systems aiming the participation of private actors.

Compensation of expenses broadens the investment horizon as it increases the yields realized by the private investors, so a wider range of enterprises is able to meet the profit expectations of the private VCs. In the co-investment HGVCs, capital is provided partially by private LPs or they are required to make joint investments with private investors. The benefits of this form derive from economies in scales and diversification. Preferential timing of cash flows results in shorter duration therefore the international rate of return (IRR) for private LPs is higher. Each of these schemes provide benefits for the private participants, but they have to take the profits and losses after their investments; therefore, these schemes cause the lowest distortions. 
Table 3. The incentive schemes in HGVC

\begin{tabular}{|c|c|c|}
\hline $\begin{array}{l}\text { Government incentive } \\
\text { scheme }\end{array}$ & Type of incentive & Effect on private participants \\
\hline Compensation of expenses & $\begin{array}{l}\text { Subsidy for covering operating } \\
\text { expenses. }\end{array}$ & $\begin{array}{l}\text { Decrease of expenses therefore } \\
\text { yields for private limited partners } \\
\text { increase. }\end{array}$ \\
\hline Co-investment & Provision of a part of capital. & $\begin{array}{l}\text { The benefits of economies of scales } \\
\text { and diversification as a result of } \\
\text { larger funds. }\end{array}$ \\
\hline Timing of cash-flows & $\begin{array}{c}\text { Private investors contribute capital } \\
\text { last and receive cash disbursement at } \\
\text { first. }\end{array}$ & $\begin{array}{l}\text { The same profits can be realized } \\
\text { under a shorter period therefore IRR } \\
\text { is higher for private investors. }\end{array}$ \\
\hline \multirow[t]{4}{*}{ Profit leverage } & $\begin{array}{l}\text { The government provides debt-like } \\
\text { capital for the fund. }\end{array}$ & $\begin{array}{l}\text { The increased leverage increases the } \\
\text { risk and return for private investors. }\end{array}$ \\
\hline & Profit ceiling for public funds. & $\begin{array}{l}\text { Private investors receive higher } \\
\text { profits than their share and without } \\
\text { taking additional risks they enjoy the } \\
\text { chance of higher returns. }\end{array}$ \\
\hline & $\begin{array}{l}\text { Partial takeover of losses that are } \\
\text { generated on the private capital. }\end{array}$ & $\begin{array}{l}\text { The private investors suffer lower } \\
\text { losses than their share that } \\
\text { decreases the semi-variance. }\end{array}$ \\
\hline & $\begin{array}{l}\text { Option to buy the share of public } \\
\text { investor. }\end{array}$ & $\begin{array}{l}\text { The private investors receive higher } \\
\text { profits than their share and without } \\
\text { taking additional risks they enjoy the } \\
\text { chance of higher returns. }\end{array}$ \\
\hline
\end{tabular}

Source: Own compilation based on Jääskeläinen et al. (2007) and Murray et al. (2012).

Profit leverage schemes modify the risk-return characteristics of the investments for private participants in order to make the VC-type investments more attractive, but at the same time these incentives influence the investment decisions. HGVC activity is, therefore, exposed to a higher distortion. Options and profit ceiling enable for the private investors to gain additional profits without taking additional risks. Thus, they lead to an increased risk-taking. Loss mitigation also attracts more risk-averse investors, but at the same time, it increases the chance of moral hazards. The various incentive schemes are not used separately; usually, these agendas incorporate their combinations. While the incentives are inevitable to attract private participants, their extended use can lead to an adverse selection, the agendas will fail in improving the funding prospects of young and innovative firms and their negative effects will exceed their benefits. The following section discusses the role of the incentive schemes in the HGVC model.

3.2.2. The model of hybrid VC. The HGVC model combines commercial rationales with economic policy principals, but its model is different than the simple mix of PVC and pure GVC models; the mix of the motives creates a model based on unique fundamentals. 
There is an extensive literature discussing the design of government backed VC initiations. There is a consensus in the literature about the role of private participation in the government backed VC agendas; public funds should be used in cooperation with private sector participants (Lerner 2009; Reid - Nightingale 2011; Karsai 2015; Baldock 2016). There are two prevalent forms of such cooperation in HGVC agendas; public funds are channelled to young and innovative firms with the government as a co-investor or by a fund of funds managed by a government agency (Karsai 2015). In the co-investment structure, public funds augment the capital of private investors and the funds are managed by private VC firms. Another widespread structure of HGVC is when public funds are invested into privately managed VCs via a fund-offunds, and only those VC firms can compete for the management of public funds that target firms what are in the scope of government agendas (Murray 2007).

Based on the international evidence there are certain criteria of efficient government backed VC agendas. Research paper in the field emphasized the role of long-term planning, the facilitation of follow-on investments, adequate scale of funds, flexible regulation, no regional restrictions, reshaping the agendas to correspond to the changing entrepreneurial environment and the agenda level exit strategy (Lerner 2009; Murray 2012; Karsai 2015; Baldock 2016). These recommendations are connected to the practical design of government backed agendas, in general, but on the other hand, they do not tackle the problems deriving from the conceptual model of HGVCs.

The HGVC model is a two-goal system with economic policy rationales connected to government funds and profit maximization motives of private participants. The specific problem of HGVCs steams from this two-goal system as the motives of participants are in conflict. Based on their economic policy motives, HGVCs target young and innovative firms, which is inconsistent with the profit maximizing behaviour of private participants; if the private investors would perceive young and innovative firms as the investment opportunities that maximize their utility, then they would appear on their market even in the absence of government interventions. Based on the assessment of private investors, young and innovative firms fall behind their profit expectations and, according to their perceptions, there are more favourable investment targets on the market. While the PVC and GVC models inevitably target young and innovative firms either led by profit maximizing or economic policy motives, the hybrid model is inconsistent in its goals and the funding of young and innovative firms does not derive from the logic of the model as it contradicts the private interests. Targeting young and innovative firms in the HGVC model relies on regulation rather than on the decisions of private participants led by economic rationales.

The underlying principle of HGVC model is that market failures lead to a sub-optimal capital supply for young and innovative firms and the perceived profit potential of these firms falls behind the expectations of private investors. By providing incentives described in the previous section, the HGVC model bridges the gap between the perceived and expected return of private investors and tries to harmonize the economic policy and profit maximizing goals. These incentives are double edged swords; they are necessary in order to crowd in private participants ${ }^{1}$ but they also inevitably lead to distortions on the market. The distortions can be

${ }^{1}$ If the private investors are willing to appear on the market in the absence of incentives, then the government intervention itself becomes redundant. 
amplified by the combined use of different incentive schemes like the mix of profit-leverage and co-investment. In the design of HGVC agendas, the proper incentive scheme plays a pivotal role and it must resonate with the development of the market; the more developed stage the market is in, the lesser level of incentive is justifiable. In this sense, the optimum of incentives is that minimum level where the private participants are willing to appear on the market.

The presence of incentives and the conflicting goals of public and private participants expose HGVCs to increased moral hazard problems. The rational interest of private participants is to benefit from the incentives while pursuing those activities that they perceive as the profit maximizing ones. Captive funds - where the LPs and GPs are not independent - represent a specific case of this problem. In their case, it is possible to internalize the economic benefits of incentives, and therefore, to gain profits without real business successes or fulfilling the economic policy goals. As a result, if the incentive scheme, investment policy and transparency of agendas are not regulated properly, in the short run, HGVCs might lead to even higher misallocation of capital than GVCs. In the long run, adverse selection might even increase as the inefficient capital allocation, and therefore, the poor performance of HGVCs signals that the targeted companies are not viable investments.

\section{CONCLUSIONS}

International evidence suggests and most research in the field agrees that governments have an important role as catalysts in the vivid entrepreneurial systems. Therefore, the questions regarding the efficient design of government backed VC agendas have utmost importance, as many of these agendas fail on a conceptual level by misunderstanding the mechanisms of VC. By creating the model of government backed VC, the current article aimed to provide a consistent theoretical framework for these agendas regarding their nature and mechanisms.

The direct effects of VC on invested firms are diverse, depending on the geographical location and the maturity of industry. In more developed entrepreneurial ecosystems, VC is able to create a value in terms of innovation and growth, while in less developed regions, $\mathrm{VC}$ has a meagre impact and invested firms, in many cases, underperform than their non-VC backed peers. These results suggest that $\mathrm{VC}$ is embedded into the entrepreneurial systems and the number and quality of young and innovative firms limit the effectiveness of investments both in the cases of private and government backed VC. These results lead to the conclusion that without a proper institutional environment young and innovative firms cannot flourish. Therefore, in the developing ecosystems, indirect government agendas prelude direct interventions.

The performance of invested firms suggests that PVC is more efficient funding scheme than any form of government backed VC. Our conclusion is that this difference is inherent in the models of different types of VC. Different goals of government backed VCs, the conflicting interests of participants and more complex moral hazard issues predestine their inferior performance relative to PVC.

In the GVC model, economic policy rationales overwrite the profit maximizing goals of PVCs; therefore, the selection of invested companies becomes biased and the problem of adverse selection may arise as non-viable firms are able to obtain capital. Moreover, it seems obvious that GVCs are not able to imitate those non-financial value added services that play a central 
role in the success of PVC. The GVC model predestines the relative underperformance of firms financed by GVCs, because economic policy rationales dominate private interests. Yet, as a catalyst, these investments might be the first steps towards a self-sustaining market, since they increase the industry level knowledge and have a pull effect on the institutions of the start-up ecosystem. Consequently, the government intervention is justifiable only in the case of supoptimal PVC activity in cases of the developing industries.

The HGVC scheme appeared in the field of direct government intervention which is, in theory, a step forward compared to GVC, as it tackles the two major problems, e.g., the lack of private interest and special expertise of private investors, by including private participants. On the other hand, the empirical evidence raises questions regarding the efficiency of HGVCs. The theoretical framework of the HGVC model shows that by crowding in private participants, this scheme creates a complex two goal system where private profit maximising interests are in conflict with the economic policy goals targeting the funding of young and innovative firms. If the private participants would perceive young and innovative firms as viable investments, then they would appear in their market even in the absence of public interventions. Incentives built into HGVC schemes provide economic benefits for private participants that bridge the gap between the expected returns of investors and the perceived returns they attribute to young and innovative firms. On the other hand, as a result of conflicting interests, the HGVC model is exposed to increased moral hazard issues and, if poorly supervised and regulated, they might lead to higher distortions on the market than GVC. Information asymmetries and moral hazard issues change the PVC model as well, but in this form, profit maximisation is a common denominator for participants and with properly designed incentives, private interests create a consistent system. However, within the two-goal system of HGVC, such harmonization is unlikely and the mix of private interests and economic policy goals create inconsistency in the model. This inconsistency is the reason why, although in theory, the involvement of private participants in HGVC is a step forward in the area of direct government interventions, in reality the success of this model relies on proper regulation and incentive system.

\section{REFERENCES}

Abernathy, W. J. - Utterback, J. M. (1978): Patterns of Industrial Innovation. Technology Review, 80(7): 41-47. Akerlof, G. A. (1970): The Market for 'Lemons': Quality Uncertainty and the Market Mechanism. Quarterly Journal of Economics, 84(3): 488-500.

Alperovych, Y. - Hübner, G. - Lobet, F. (2015): How Does Governmental Versus Private Venture Capital Backing Affect a Firm's Efficiency? Evidence from Belgium. Journal of Business Venturing, 30(4): 508525.

Avnimelech, G. - Teubal, M. (2006): Creating Venture Capital Industries that Co-evolve with High Tech: Insights from an Extended Industry Life Cycle Perspective of the Israeli Experience. Research Policy, 35(10): 1477-1498.

Baldock, R. (2016): An Assessment of the Business Impacts of the UK's Enterprise Capital Funds. Environment and Planning C: Government and Policy, 34(8): 1556-1581.

Baumol, W. J. (2002): The Free-Market Innovation Machine: Analyzing the Growth Miracle of Capitalism. Princeton: Princeton University Press. 
Becker, R. - Hellmann, T. (2005): The Genesis of Venture Capital - Lessons from the German Experience. In: Kanniainen, V. - Keuschnigg, C. (ed.): Venture Capital, Entrepreneurship, and Public Policy. CESifo Seminar Series: MIT Press, pp. 33-68.

Becsky-Nagy, P. (2016): The Special Aspects of Venture Capital's Value Creating Mechanisms in Hungary. Journal of Entrepreneurship Management and Innovation, 12(6): 31-56.

Becsky-Nagy, P. - Fazekas, B. (2015): Investment or Learning Curve? The Effects of EU and Government Funds on the Development of the Hungarian Venture Capital Market. Public Finance Quarterly, 60(2): 238-248.

Becsky-Nagy, P. - Fazekas, B. (2017): Is the State on the Ball? The Effect of the State's Role on the Demand Side of Venture Capital. Economic Review, 64(5): 507-527.

Berger, A. - Udell, K. F. (1998): The Economics of Small Business Finance: The Roles of Private Equity and Debt Markets in the Financial Growth Cycle. Journal of Banking and Finance, 22(6-8): 613-673.

Bertoni, F. - Tykova, T. (2012): Which Form of Venture Capital is Most Supportive of Innovation? ZEWCentre for European Economic Research, Discussion Paper, No. 12-018.

Bertoni, F. - Colombo, M. - Quas, A. (2015): The Patterns of Venture Capital Investment in Europe. Small Business Economics, 45(3): 543-560.

Bower, J. L. - Christensen, C. M. (1995): Disruptive Technologies: Catching the Wave. Harvard Business Review, 73(1): 43-53.

Brander, J. A. - Du, Q. - Hellmann, T. F. (2015): The Effects of Government-Controlled Venture Capital: International Evidence. Review of Finance, 19(2): 571-618.

Brau, J. C. - Brown, R. A. - Osteryoung, J. S. (2004): Do Venture Capitalists Add Value to Small Manufacturing Firms? An Empirical Analysis of Venture and Non-Venture Capital-Backed Initial Public Offerings. Journal of Small Business Management, 42(1): 78-92.

Chemmanur, T. J. - Krishnan, K. - Nandy, D. K. (2011): How Does Venture Capital Financing Improves Efficiency in Private Firms? A Look Beneath the Surface. Review of Financial Studies, 24(12): 40374090.

Coakley, J. - Hadass, L. - Wood, A. (2007): Post-IPO Operating Performance, Venture Capital and the Bubble Years. Journal of Business Finance \& Accounting, 34(9-10): 1423-1446.

Cressy, R. (2002): Funding Gaps: A Symposium. The Economic Journal, 112(477): F1-F16.

Croce, A. - Marti, J. - Murtinu, S. (2013): The Impact of Venture Capital on the Productivity Growth of European Entrepreneurial Firms: 'Screening' or 'Value Added' Effect? Journal of Business Venturing, 28(4): 489-510.

Cumming, D. J. - MacIntosh, J. G. (2006): Crowding Out Private Equity: Canadian Evidence. Journal of Business Venturing, 21(5): 569-609.

Cumming, D. J. - Johan, S. A. (2010): Venture Capital Investment Duration. Journal of Small Business Management, 48(2): 228-257.

Cumming, D. J. - Johan, S. A. (2016): Venture's Economic Impact in Australia. Journal of Technology Transfer, 41(1): 25-59.

Cumming, D. - Grilli, L. - Murtinu, S. (2017): Governmental and Independent Venture Capital Investments in Europe: A Firm-Level Performance Analysis. Journal of Corporate Finance, 42(2): 439459.

Devenow, A. - Welch, I. (1996): Rational Herding in Financial Economics. European Economic Review, 40(3-5): 603-615.

Engel, D. - Keilbach, M. (2007): Firm-Level Implications of Early-Stage Venture Capital Investment: An Empirical Investigation. Journal of Empirical Finance, 14(2): 150-167. 
Fazekas, B. (2016): Value-Creating Uncertainty - A Real Options Approach in Venture Capital. Financial and Economic Review, 15(4): 151-166.

Fazekas, B. - Becsky-Nagy, P. (2018): The State in its Risk-Capital Role. Economic Review, 65(12): 1257-1280.

Fried, V. H. - Hisrich, R. D. (1994): Towards a Model of Venture Capital Decision Making. Financial Management, 23(3): 28-37.

Gompers, P. A. (1995): Optimal Investment, Monitoring and Staging of Venture Capital. The Journal of Finance, 50(5): 1461-1489.

Gompers, P. A. - Lerner, J. (1998): What Drives Venture Capital Fundraising? Brookings Papers on Economic Activity: Microeconomics, 149-192.

Grilli, L. - Murtinu, S. (2014): Government, Venture Capital and the Growth of European High-Tech Entrepreneurial Firms. Research Policy, 43(9): 1523-1543.

Hall, B. H. (2002): The Financing of Research and Development. Working Paper, No. E01-311, University of California, Berkley.

Harding, R. (2002): Plugging the Knowledge Gap: An International Comparison of the Role for Policy in the Venture Capital Market. Venture Capital: An International Journal of Entrepreneurial Finance, 4(1): 59-76.

Harris, R. S. - Jenkinson, T. - Kaplan, S. N. (2014): Private Equity Performance: What Do We Know? The Journal of Finance, 69(5): 1851-1882.

Hellmann, T. - Puri, M. (2000): The Interaction between Product Market and Financing Strategy: The Role of Venture Capital. The Review of Financial Studies, 13(4): 959-984.

Invest Europe (2016): European Private Equity Activity Data 2015.

Invest Europe (2019): European Private Equity Activity Report 2018.

Jääskeläinen, M. - Maula, M. - Murray, G. (2007): Profit Distribution and Compensation Structures in Publicly and Privately Funded Hybrid Venture Capital Funds. Research Policy, 36(7): 913-929.

Jensen, M. C. - Meckling, W. H. (1976): Theory of the Firm: Managerial Behavior, Agency Costs and Ownership Structure. Journal of Financial Economics, 3(4): 305-360.

Kaplan, S. N. - Schoar, A. (2005): Private Equity Performance: Returns, Persistence and Capital Flows. Journal of Finance, 60(4): 1791-1823.

Karsai, J. (2015): Squaring the Circle? - Government as Venture Capital Investor. Külgazadság, 59(1): 6293.

Karsai, J. (2018): Government Venture Capital in Central and Eastern Europe. Venture Capital: An International Journal of Entrepreneurial Finance, 20(1): 73-102.

Kenney, M. (2011): How Venture Capital Became a Component of the US National System of Innovation. Industrial and Corporate Change, 20(6): 1677-1723.

Kirchhoff, B. A. (1993): Entrepreneurship and Dynamic Capitalism: The Economics of Business Firm Formation and Growth. Westport: Praeger.

Lane, J. E. (2000): The Public Sector; Concepts, Models and Approaches. London: SAGE Publications.

Lerner, J. (1999): The Government as Venture Capitalist: The Long-Run Impact of the SBIR Programs. The Journal of Business, 72(3): 285-318.

Lerner, J. (2002): When Bureaucrats Meet Entrepreneurs: The Design of Effective 'Public Venture Capital' Programs. The Economic Journal, 112(477): F73-F84.

Lerner, J. (2003): Venture Capital and Private Equity: A Course Overview. International Journal of Entrepreneurship Education, 1(3): 359-384.

Lerner, J. (2009): Boulevard of Broken Dreams: Why Public Efforts to Boost Entrepreneurship and Venture Capital Have Failed and What to Do about It. Princeton: Princeton University Press. 
Luukkonen, T. - Deschryvere, M. - Bertoni, F. (2013): The Value Added by Government Venture Capital Funds Compared with Independent Venture Capital Funds. Technovation, 33(4-5): 154-162.

MacMillan, I. C. - Kulow, D. M. - Khoyilian, R. (1988): Venture Capitalists' Involvement in Their Investments: Extent and Performance. Journal of Business Venturing, 4(1): 27-47.

Manigart, S. - Baeyens, K. - Hyfte, W. V. (2002): The Survival of Venture Capital Backed Companies. Venture Capital: An International Journal of Entrepreneurial Finance, 4(2): 103-124.

Mason, C. M. - Harrison, R. (1997): Business Angel Networks and the Development of the Informal Venture Capital Market in the UK: Is There Still a Role for Public Policy? Small Business Economics, 9(2): 111-123.

Megginson, W. L. - Weiss, K. A. (1991): Venture Capitalist Certification in Initial Public Offerings. The Journal of Finance, 46(3): 879-903.

Metrick, A. (2007): Venture Capital and the Finance of Innovation. New York: John Wiley \& Sons.

Murray, G. (2007): Venture Capital and Government Policy. In: Landstrom, H. (ed.): Handbook of Research on Venture Capital. Cheltenham: Edward Elgar, pp. 113-154.

Murray, G. C. - Cowling, M. - Liu, W. - Kalinowska-Beszczynska, O. (2012): Government Co-Financed 'Hybrid' Venture Capital Programmes: Generalizing Developed Economy Experience and its Relevance to Emerging Nations. Kauffman International Research and Policy Roundtable, Liverpool, 11-12 March 2012.

Nightingale, P. - Murray, G. - Cowling, M. - Baden-Fuller, C. - Mason, C. - Siepel, J. - Hopkins, M. Dannreuther, C. (2009): From Funding Gaps to Thin Markets: UK Government Support for Early-Stage Venture Capital. London: NESTA.

Peneder, M. R. (2010): The Impact of Venture Capital on Innovation Behaviour and Firm Growth. Venture Capital: An International Journal of Entrepreneurial Finance, 12(2): 83-107.

Phalippou, L. (2010): Venture Capital Funds: Flow-Performance Relationship and Performance Persistence. Journal of Banking and Finance, 34(3): 568-577.

Phalippou, L. - Gottschalg, O. (2009): The Performance of Private Equity Funds. Review of Financial Studies, 22(4): 1747-1776.

Philpott, T. (1994): Banking and New Technology Small Firms: A Study of Information Exchanges in the Financing Relationship. In: Oakey, R. P. - During, W. (ed.): New Technology-Based Firms in the 1990. London: Paul Chapman Publishing, pp. 68-80.

Pierrakis, Y. (2010): Venture Capital: Now and after the Dotcom Crash. London: NESTA Research Report, $\mathrm{VC} / 57$.

Pommet, S. (2017): The Impact of the Quality of VC Financing and Monitoring on the Survival of IPO Firms. Managerial Finance, 43(4): 440-451.

Puri, M. - Zarutskie, R. (2012): On the Lifecycle Dynamics of Venture-Capital and Non-Venture-Capital Financed Firms. The Journal of Finance, 67(6): 2247-2293.

Reid, A. - Nightingale, P. (2011): The Role of Different Funding Models in Stimulating the Creation of Innovative New Companies. What is the most Appropriate Model for Europe? A Report to the European Research Area Board. (Study funded by the European Commission, Directorate-General Research).

Rin, da M. - Hellmann, T. F. - Puri, M. (2011): A Survey of Venture Capital Research. NBER Working Paper Series, No. 17523.

Roszko-Wójtowicz, E. - Białek, J. (2018): Diverse Approaches to the Multidimensional Assessment of the Innovation Level - The Case of the EU Member Countries. Acta Oeconomica, 68(4): 521-547.

Sahlman, W. A. (1990): The Structure and Governance of Venture-Capital Organizations. Journal of Financial Economics, 27(2): 473-521. 
Scherer, F. M. - Ross, D. (1990): Industrial Market Structure and Economic Performance. Boston: Houghton Mifflin.

Schilder, D. (2006): Public Venture Capital in Germany: Task Force or Forced Task? Bergakademie Freiberg, Faculty of Economics and Business Administration, Working Paper, No. 12.

Veugelers, R. (2011): Mind Europe's Early-Stage Equity Gap. Policy Contributions from Brugel.

Open Access. This is an open-access article distributed under the terms of the Creative Commons Attribution 4.0 International License (https://creativecommons.org/licenses/by/4.0/), which permits unrestricted use, distribution, and reproduction in any medium, provided the original author and source are credited, a link to the CC License is provided, and changes - if any - are indicated. (SID_1) 